Article

\title{
(Un)Sustainable Development of Minors in Libyan Refugee Camps in the Context of Conflict-Induced Migration
}

\author{
Magdalena El Ghamari ${ }^{1, *}$ and Monika Gabriela Bartoszewicz ${ }^{2, *(1)}$ \\ 1 Institute of Political Sciences and International Relations (INPISM), Collegium Civitas University, \\ 00-901 Warsaw, Poland \\ 2 Department of Political Science, Masaryk University, 60200 Brno, Czech Republic \\ * Correspondence: magdalena.elghamari@civitas.edu.pl (M.E.G.); bartoszewicz@mail.muni.cz (M.G.B.)
}

Received: 12 May 2020; Accepted: 31 May 2020; Published: 3 June 2020

check for updates

\begin{abstract}
This paper looks at the challenges to the sustainable development of migrant and refugee children in Libyan refugee camps and migrant detention centres. Libya, next to Syria, is still the most destabilised Arab country with a myriad of conflicting parties, warlords, militias, terrorist organisations as well as smugglers and traffickers that continuously compete in a complex network of multidimensional power struggles. Our single case study based on ethnographic fieldwork adopts the human security approach, which provides security analysis with an inherently "sustainable" dimension. In the paper we provide an overview of the empirical study carried out in seven Libyan refugee camps (Tripoli, Tajoura, Sirte, Misrata, Benghazi, Derna and Tobruk) between 2013 and 2019. Our findings show that for refugee children even everyday activities pose a danger to health and life, and the many threats to their security encompass a broad spectrum from health to safety, from education to falling prey to bundlers from terrorist organisations and paramilitary militias. These issues, undoubtedly pertinent on the individual level of analysis, are further exacerbated by the underlying, conflict-induced factors and preclude a safe and secure environment.
\end{abstract}

Keywords: Libya; violent conflicts; children; human security; migration; refugee camps; sustainable development

\section{Introduction}

Violent conflicts, considered the most traditional security threat, have taken an entirely new form, and this transformation has far-reaching ramifications for all the actors involved, especially civilians, who have become an even more vulnerable group. Among non-combatants, children need the most protection from a variety of threats. Children are directly and indirectly affected by conflict, subject to the consequences of war and its auxiliaries such as terrorism, piracy, the activities of organised crime groups, climate change (famines, draughts) and resource scarcity. The human security paradigm that gives moral primacy to human beings over state interests provides an analytical framework which encompasses this full spectrum of threats. As a normative alternative to more traditional security analyses, human security also offers a more ethical foundation for policymaking. In other words, the human angle provides the concept of security with an inherently "sustainable" dimension. Our paper applies the human security framework to a Libyan case study.

At present, Libya, next to Syria, is the most destabilised Arab country, with a myriad of conflicting parties, warlords, militias, terrorist organisations as well as smugglers and traffickers that continuously compete in a complex network of multidimensional power struggles. Our single case study analysis presents data on the problem of human security challenges epitomised by the 
unsustainable development of minors in Libyan refugee camps. The data are subsequently used to typify the issues connected with the unsustainable development of migrant and refugee children.

The main asset of our paper is the robust empirical material it provides with regard to this relatively under-researched topic, in a field that is hard to reach. Research on post-Gaddafi Libya is scant. Given the challenges posed by the ongoing conflict, most of the available knowledge is derived either from the media or anecdotal evidence. Even the existing body of literature on migration-related problems in Libya lacks a rigorous and systematic analysis precisely due to fieldwork difficulties. In the broader context, detached from the geographic location, the available literature focused on refugee children is usually set in the country of destination, not in a transit country [1], and most of the time it offers an issue-specific perspective, focused narrowly on mental health [2,3], educational development [4] or family-related problems [5]. Alternatively, it scrutinises individual factors affecting specific developmental outcomes [6].

In contrast, taking the stunted development of refugee children in Libyan camps as a given, we look closely at how the complex security situation of the "new wars", and particularly the specific conditions and phenomena accompanying modern conflicts, observed during ethnographic fieldwork, can be combined with causal gravity with regard to poor developmental outcomes. In particular, we provide specific information on the physical characteristics of the Libyan refugee camps and show how this very specific environment affects children's development. This approach brings another added value to our research, for instead of going down the beaten track of well-known arguments that permeate the academic debates on the subject, we provide an interdisciplinary link to security studies. In this context, conflict serves as a specific angle in the human security approach, allowing us to anchor the sustainable development debate in the political sciences. This empirical bridge can be appreciated both by political scientists and representatives of other social sciences, as it prevents the human security approach from being reduced to a mere normative exercise without any reference to actual research.

In what follows, the (un)sustainability triad—conflicts, migration and minors—is brought together in one analytical framework, under the umbrella of the human security paradigm. After the theoretical introduction and methodological overview, the case study analysis is presented. The contextual and empirical dimensions precede the discussion of the main findings.

\section{The Unsustainability Triad: Conflicts, Migration and Minors}

Conflicts are taken somewhat for granted in the study of sustainability, which inevitably essentialises problems around them and prevents effective counter-actions. Undoubtedly, "violent conflict" is an umbrella concept that lumps together various phenomena. Whereas the term hints at the fact that violence erupts as a consequence of mutual hostilities resulting from the incompatibilities dividing the rival actors [7] (p. 29), it simultaneously blurs the differences crucial to understanding the problem we analyse in our case study, which is torn by different wars and the more general armed conflicts.

Defining war is tricky in the sense that even the Oxford Handbook of War [8] does not provide a clear-cut formula. Broadly speaking, war can be understood as a conflict between two communities that are politically, economically and ideologically integrated, and where all the available military and non-military resources necessary for the achievement of the set goal are engaged [9]. This concept led to further clarifications and made it possible to distinguish between war between states (interstate or international war) and war within a state (internal or civil war) [10]. This has been reinforced by Mary Kaldor [11], who noticed the qualitative difference between the "old wars" fought between states under the code of laws and by uniformed men in standing armies who fought pitched battles in formations, and what she called "new wars". In line with Kaldor's thinking, these new wars were hardly wars at all, and the word "conflict" was found to be much better suited to describe the clashes between various actors, with fuzzy distinctions between soldiers and civilians, no geographic 
demarcation of the battlefield or front and rear areas and certainly no commonly respected rules such as the Geneva Conventions.

Although the new wars theorists have had to withstand a scathing critique [12] regarding what is precisely "new" in their theory, further research capitalised on this conception, developing and refining the new wars thesis that has been commonly employed to analyse the various conflicts at the turn of the 20th and 21st centuries. [13] (p. 93) provides us with a long list of these derivatives, encompassing new and old wars, the third kind of war, uncivil wars, intrastate wars, resource conflicts, variants of ethnic war, internal wars, ideological civil wars, communal wars, low-intensity conflicts, small wars, insurgencies, complex emergencies and post-modern wars. These considerations are important, because virtually all of these terms have been used to describe the situation in Libya. In this context, the Libyan case is not so much an ideal-type as paradigmatic example [14] (p. 77) of a multidimensional conflict and its auxiliaries, a situation that was frequently referred to by our respondents.

All the above theorising has essentially one goal: to show that the threats considered to be the most traditional now take an entirely new form and that this transformation has far-reaching consequences for all the actors involved [15]. This is essential because contemporary violent conflicts, notices Conteh-Morgan [7], seem to be increasing in scope (extent), intensity (gravity) and duration. And although large-scale violent conflicts will continue to be a significant concern in the 21st century [16] (p. XIII), in recent times intrastate warfare has been more frequent than interstate warfare [17]. Furthermore, in modern wars, civilians are an even more vulnerable group; this renders their situation even more demanding, particularly in the context of challenges to sustainable development. Civilians are also particularly affected by the auxiliaries of contemporary conflicts [18], such as terrorism, piracy, activities of organised crime groups, climate change (famines, draughts) and resource scarcity [19]. Since internal conflicts often go beyond the framework of one community or the borders of the country or area in which they take place, a purely local or internal conflict may have supra-regional or global repercussions [20]. This spill-over effect results in an increase in migration on a global scale, caused by political, economic, social and environmental factors. According to the International Migration Report [21], the share of migrants in the total population worldwide increased from 2.8 in 2000 to 3.4 per cent in 2017. This is further augmented by the fact that various forms of irregular violent conflicts, such as rebellions, insurgencies, guerrilla warfare and civil wars, are typically characterised by an extraordinary level of disorganised violence [22], directed by the combatants towards each other and particularly towards the civilian population.

Among non-combatants, children are the most vulnerable group. Children, like others, are directly and indirectly affected by conflict, becoming subject to the consequences of war. Indeed, many argue [23] (p. 1) that the contemporary complexities of armed conflict impinge upon children in historically new ways. This is evidenced by the fact that, in 2018, UNICEF [24] verified more than 24,000 grave violations against children, including killing, maiming, sexual violence, abductions, denial of humanitarian access, child recruitment and attacks on schools and hospitals, which marks a threefold rise since 2010. Simultaneously, a Save the Children report [25] concludes that five times as many children have died in conflict zones than fighters between 2013 and 2017. For this reason, in our analysis we take the stunted development of refugee children as a given. The primary goal of sustainable development is to "ensure that all human beings can fulfil their potential in dignity and equality" [26]. Such conceptualisation allows us to account for basic security needs as well as health and human capital (education). Our fieldwork has also pointed us to issues connected with mental well-being, self-esteem and related identity problems anchored in the dignity and equality criteria set by the UN, specifically the negative impact of the refugee camps' physical environment on children's sustainable development.

\section{Analytical Framework and Methodology}

The question arises as to which analytical framework can possibly connect issues as diverse as sustainable development, violent conflicts, minors and migration in one coherent conceptual structure. 
This is where the human security paradigm — which encompasses the security of groups and individuals in a wide variety of dimensions, from military security to political, economic, social and environmental security, and in all directions: "upwards to international institutions, downwards to regional or local government, sideways to nongovernmental organisations, to public opinion and the press, and to the abstract forces of nature or of the market" [27] (p. 55)—can be useful. In contrast with the national and international security paradigms, which are two state-centred approaches, this third perspective on security gives moral primacy to human beings and the community of humankind over and above the interests of states or the international society to which they belong.

The human security paradigm considers personal security to be a fundamental problem of international relations and not merely a matter for the domestic politics of the state concerned, on the grounds that the security of the state and the security of the individual are fundamentally interconnected and one cannot exist without the other. In addition to a departure from the state-centric approach, whereby the individual becomes the primary referent object, this paradigm engages with the concept of security from a different angle, that encompasses a wide spectrum of threats. Not only is individual security considered of far greater importance than that of the state, but also the security of the person is divorced from the security of the state, as states themselves are able to threaten the security of individuals [28].

Since the publication of the 1994 UNDP Human Development Report, the UN has been a leading proponent of the concept of human security. The document's main concern was linking social, humanitarian and economic issues, given that critics dismissed human security on the grounds that it merely supplants the word "development". As Roland Paris [29] (p. 95) concluded, the proponents of the human security paradigm have been accused of "appropriating" the term "security", which conveys urgency, demands public attention and commands governmental resources in ways that mere "development", sustainable or not, would never be able to.

Equally fundamental to the problem under study is the fact that human security introduces a distinctively normative alternative perspective to traditional security analyses [30] and provides an ethical background for policymaking. A normative view of security is predicated upon values, ideas and identities. This renders security an inherently normative concept, because without it human life is reduced to a basic struggle for survival, and it also implies hard choices between competing values (e.g., between the security of the state and the security of the person) when it comes to acting on security dilemmas. For this reason, human security is concerned not only with the ends or goals of security policy but also with the means used to pursue them. Consequently, security policy itself came to be regarded as a series of moral dilemmas to which there can be no easy fixes or quick solutions. In other words, the human angle imbues the concept of security with an inherently "sustainable" dimension, concerning both the socio-political milieu and the physical environment of the individual.

In what follows, the above analytical framework will be applied to the Libyan case study. A case study analysis, i.e., a study in which a single country forms the basic unit of analysis [31] (p. 84), remains the most common method of research in the social sciences, perfectly suited to characterise a phenomenon that seems to be especially apparent and to explore it fully within the existing theory. As observed by [32] (pp. 12, 62), a careful and insightful examination of a single case study, although often seen as theoretical and purely descriptive, can explicate, if done well, a concept that appears to be particularly evident in one national setting and use the country study to develop that conceptual framework further.

While generalisations from single-country studies will always be limited, since the country unit itself is bound by particular characteristics [31] (p. 93), a single case, if properly constructed and researched, can be used to expand the knowledge base of political science and to illuminate, or even test directly, selected theories or paradigms [32] (p. 138).

With these caveats in mind, our purposes were (1) to collect information on the problem of human security challenges epitomised by the unsustainable development of minors in Libyan refugee camps, especially in an area destabilised by conflicts and hard to reach (which endows any empirical 
material with additional value); and (2) to use the collected data to typify the issues connected with the unsustainable development of minors. This means that we pursued a "disciplined-configurative" study [33] whereby the Libyan case is used to draw conclusions with broader applicability. This is possible because a descriptive case study can often make a contribution to discovering specific patterns and foster our understanding of multiple causations and complex interactions among variables, even if the findings are located in a very particular historical and cultural milieu. Therefore, the real advantage of our methodological approach is that it explains the intricate causal dependencies-using a theoretical triangulation strategy via multiple lenses (conflict, minors, migration) - in such a way that the variance of the error was minimised by cross-checking the empirical data by a team of two researchers.

\section{Libyan Case Study}

\subsection{Case Overview}

The events that began in Libya with the Day of Anger, on 17 February 2011, when massive anti-government protests were organised across the country, have resulted in an unstable country that is politically and militarily divided, beleaguered by social and cultural tensions, struggling with terrorism and affected by a mass exodus of refugees. Of these events, certain milestones should be mentioned. The Operation Odyssey Dawn (19 March 2011), carried out by US forces and the allied armed forces of the Netherlands, Norway, Qatar, Denmark, United Arab Emirates, Spain, and Italy, was the international crisis response operation. It was an air, sea and land attack campaign carried out to protect civilians, in particular in eastern Libya, against actions taken by the army of Muammar al-Gaddafi. Simultaneously (19-31 March 2011), the French Operation Harmattan began, a military operation following the international crisis response under the auspices of the United Nations, aimed at ensuring compliance with UN Security Council Resolution (UNSCR) 1973. The second military operation, strictly naval and air, was Operation Unified Protector (OUP), conducted from 27 March to 31 October 2011, under the auspices of NATO. The OUP was aimed at enforcing the provisions of UNSCR 1970 and 1973, including the establishment of a no-fly zone. The events that followed these military operations were critical for the later situation in Libya, including the current bid for power by forces rallied behind General Khalifa Haftar [34].

The collapse of the dictatorship and the death of Muammar Gaddafi enabled many tribal and social tensions to come to the fore. The weakened state could not prevent or counter the growing extremism and increased activity of terrorist organisations, of which the so-called Islamic State was the most notorious but by no means the only one operating in this region. The power struggles between the local coalition partners often lapsed into a grey zone of international law and contributed to the deteriorating situation in Libya, which has never returned to its former condition. The state has also had to face economic collapse, resource scarcity and rifts between migrants, internally displaced persons (IDPs) and host communities, as well as between Arabic and non-Arabic speakers.

After 42 years of dictatorship, the political vacuum led to substantial social unrest. Over time, there has been a progressive radicalisation of social, political and, in many cases, religious beliefs. This polarisation of extreme social moods has manifested itself in many ways, from family vendettas to political feuds and to the skyrocketing aversion to strangers in a formerly hospitable society [34]. There was also a significant change in the demographic structure: more women, fewer men and vast numbers of children. Drugs and alcohol use skyrocketed. Additionally, many Libyans have experienced internal exile. Critical infrastructure, including hospitals, airports, networks and telecommunications, was destroyed. Similarly, numerous historical monuments were annihilated. There was a massive demand for necessities, medicines and building materials. However, the climate change worsened the humanitarian situation in the country, especially in the capital city of Tripoli. This worsened poverty and caused rising food prices. At the same time, the changes also affected the Libyan economy, warping the whole structure of the state. The change in the currency caused a physical lack of banknotes and a drop in inflation, which encouraged the growing "grey economy" and already rampant corruption. 
It also needs to be remembered that the Guardia di Finanza seized the assets of the al-Gaddafi regime, which amounted to 1.1 billion Euros in two financial funds: the LIA (Libyan Investment Authority) and LAFICO (Libyan Arab Foreign Investment Company), as well as governmental shares in Unicredit Bank, ENI energy group, Finmeccanica, Fiat Industrial and Juventus FC. Additionally, 43 tonnes of gold disappeared. The above nearly renders the problems of gas extraction and the illicit antiquities trade inconsequential.

At present, Libya, next to Syria, is still the most destabilised Arab country, with a myriad of conflicting parties, warlords, militias, terrorist organisations as well as smugglers and traffickers that constantly compete in a complex network of multidimensional power struggles. Human trafficking is crucial, especially in the context of the 2015 migration crisis, which permanently changed the regional and international security architecture [35]. Since 2017, Libya has been the main migration route from Africa to Europe. From the South come migrants fleeing war-torn areas. Refugees from the East try to escape the ongoing local conflicts there. Those who come from the West seek asylum from poverty and illegitimate warlords. Libya is not a signatory to the 1951 Convention on Refugees, a multilateral treaty that sets out the responsibilities of states towards asylum seekers. However, Libya is a party to the regional Organization of African Unity Convention Governing the Specific As pects of Refugee Problems in Africa (1969), which encompasses the very nature of the 1951 Convention. However, Libya has not incorporated the convention into domestic legislation. This has prevented the development of a migrant governance system or a dedicated institution to deal with migrant concerns, which has left authorities without a compass to guide them in upholding international norms and standards when deliberating on policy and interacting with migrants and asylum seekers. According to the Libyan legal system, "illegal migrants will be placed in detention and condemned to forced labour in jail or a fine of 1000 Libyan dinars and be expelled from the Libyan territory after serving a sentence" (Article 6 of Law No. 19 of 2010 on Combating Irregular Migration), whereas "all foreigners residing in Libya had to legalize their stay in Libya within two months after entry into force of the law" (Article 11 of Law No. 19 of 2010 on Combating Irregular Migration); otherwise, they are to be considered illegal migrants and subject to penalties under Article 6.

There are three main entry points for refugees and migrants into Libya: (1) via Niger or Chad, along Libya's southern borders; (2) via Algeria, on the northwestern or southwestern border; and (3) via the eastern route, with refugees and migrants reaching the south-eastern region of Alkufra transiting through both Chad and Sudan. Secondary routes include entering Libya via Egypt, through the coastal town of Emsaed. Corresponding to the main entry points into the country, there are two main routes which refugees and migrants in Libya use to reach the coast, via the east and west of the country, respectively. In 2017, refugees and migrants who entered Libya from Algeria or Niger used the western route to reach the coast, while individuals entering from Chad and Sudan used the eastern route to Alkufra, and from there joined the western route. That year, it was found that the northeast of Libya was no longer an important area for migration due to recurrent fighting in the area [36].

It also needs to be specified that while some in the groups mentioned above are voluntary migrants, others are forced to migrate either by dire circumstances or simply by becoming a commodity on the market ruled by smugglers, who often operate under false pretences. These human trafficking cartels prey on those who come from inland Africa. Armed militias control the border between Niger and Libya, where a network of smugglers selling drugs, oil, artwork, telephones, counterfeit money, humans and documents operate a market worth hundreds of thousands of Libyan dinars. As elucidated in our earlier research, many migrants who enter Libya on their way to Europe call it a "purgatory". Furthermore, some of those who arrive in Libya decide to take their chances and travel onward through the most dangerous stretch of the Mediterranean. Unlike many others, who, mainly due to lack of funds to travel further, or who get swept up in the ongoing struggle of General Khalifa Haftar, remain stuck in the country [34]. 


\subsection{Fieldwork}

As of February 21, 2020, in Libya, there were 356,572 Libyans classified as IDPs, 447,707 as returned IDP and 47,647 refugees and asylum seekers. Furthermore, the International Organisation for Migration [37] estimated that there were 700,000 to 1 million migrants in Libya. Given that $44 \%$ of the indigenous Libyan population is under 24, nearly the same percentage of refugees and IDPs fall into the "vulnerable migrant" category accounting for minors and other particularly unprotected groups [38].

Children in Tripoli, Derna and other urban areas in the western and southern parts of the country are particularly vulnerable. After the attack of the Libyan National Army on the Government of National Accord (GNA) in Tripoli in April 2019, violence increased. In one city, Tripoli, more than 150,000 people, of whom 90,000 were children, were forced to flee their homes. This included 60,000 refugee and migrant children living in the urban and peri-urban areas of Tripoli and its surroundings [39]. The largest clusters of minors were in the vicinity of the most unstable towns, where there is still the highest activity of paramilitary militias and organised criminal and smuggling groups: Musrata, Sirte and Tripoli, where migrants are left to the mercy of the militias, not to mention the recent phenomenon of open slave markets.

The majority of IDPs and migrants seek help in various detention centres, resettlement centres and refugee camps. Migrant detention centres are controlled by the Department for Combating Illegal Migration (DCIM), in the Ministry of Interior. Yet, in reality, the Ministry has little authority over the centres. An official of the Ministry admitted to the UN that: "In Tripoli, there are 13 illegal detention centres, managed by the armed militia. We cannot even get close to their areas because we risk our lives". Estimating the factual number of centres and camps in Libya is not an easy task. According to an Amnesty International report [40], there were 31 to 34 detention centres, 24 of which were run by the DCIM, but many more centres run by local militias. The Libyan government revealed that there were 23 detention centres, holding between 9000 (February 2019) and 7500 (December 2019) asylum seekers. According to the Ministry of Interior, there were between 5000 and 6000 refugees and migrants, of whom 2000 were minors (December 2019). The data provided by the Libyan government did not match those presented by the IOM [41] or the UN High Commissioner for Refugees (UNHCR) [42], indicating 145,000 children, of whom 9\% were exposed to serious violations of children's rights. Data obtained from the Tobruk-based GNA were entirely different and indicated that of 23 centres, 19 operated illegally and should be closed as soon as possible, while the remainder should be managed by the military, which was the only guarantor of security. Despite a large number of scientific articles and reports, the data are so diverse that it is difficult to determine which figures are accurate, especially when the situation is changing so quickly. No available statistics include the number of births in Libyan camps. Our estimates suggest that between 2013 and 2015, 1700 children were born in the centres, and by 2019 the number of births increased to 4700 .

Before our arrival in Libya in 2013, according to the data we obtained directly from all 23 camps, there were 25,000 minors housed there, and in the seven we selected for fieldwork, about 8000 . Nevertheless, in many cases, these were merely rough estimates, as systematic, quantitative data are not available, which demonstrates the research difficulty. Table 1 juxtaposes the officially estimated figures with the numbers we actually encountered during our field visits. 
Table 1. Number of expected, actual and interviewed children during 2013-2015 fieldwork.

\begin{tabular}{cccccccccc}
\hline Camp & $\begin{array}{c}\mathbf{2 0 1 3} \\
\text { Expected } \\
\text { Number }\end{array}$ & $\begin{array}{c}\mathbf{2 0 1 3} \\
\text { Actual } \\
\text { Number }\end{array}$ & $\begin{array}{c}\mathbf{2 0 1 3} \\
\text { Interviewed }\end{array}$ & $\begin{array}{c}\mathbf{2 0 1 5} \\
\text { Expected } \\
\text { number }\end{array}$ & $\begin{array}{c}\mathbf{2 0 1 5} \\
\text { Actual } \\
\text { Number }\end{array}$ & $\begin{array}{c}\mathbf{2 0 1 5} \\
\text { Interviewed }\end{array}$ & $\begin{array}{c}\mathbf{2 0 1 9} \\
\text { Expected } \\
\text { Number }\end{array}$ & $\begin{array}{c}\mathbf{2 0 1 9} \\
\text { Actual } \\
\text { Number }\end{array}$ & $\begin{array}{c}\mathbf{2 0 1 9} \\
\text { Interviewed }\end{array}$ \\
\hline Triq al Sika/Tripoli & 200 & 450 & 42 & 310 & 850 & 57 & No data & 350 & 36 \\
\hline Tajoura & 200 & 370 & 52 & 149 & 480 & 54 & No data & 206 & 34 \\
\hline Sirte & 100 & 220 & 30 & 150 & 420 & 40 & No data & 248 & 22 \\
\hline Misrata & 130 & 250 & 5 & 90 & 450 & 9 & No data & 130 & 26 \\
\hline Benghazi & 100 & 209 & 41 & 135 & 409 & 16 & No data & 130 & 33 \\
\hline Derna & 50 & 230 & 31 & 89 & 312 & 18 & No data & 219 & 14 \\
\hline Bab Zaytouna/Tobruk & 80 & 180 & 12 & 112 & 216 & 18 & No data & 268 & 10 \\
\hline Total & 860 & 1909 & 213 & 1035 & 3137 & 250 & No data & 1551 & 160 \\
\hline
\end{tabular}

Among the characteristic features of all the centres we visited-Triq al Sika/Tripoli, Tajoura (which is officially closed but still functioning), Sirte, Misrata, Benghazi Ganfouda, Derna and Bab Zaytouna/Tobruk-we found incomplete data; no legal, stable regulations; unknown management and the simultaneous rule of katibas (militias); lack of confidence in the existing security measures; torture and punishment; inhumane conditions; and recruitment of migrants to militias and terrorist organisations. These facilities can be classified as open, semi-open and closed. As of February 2020, some of the facilities no longer existed because of the bombings and ongoing internal conflicts, especially in the western part of Libya [42]. It is estimated that (as of 30 November 2019) there were about 355,672 thousand people in those hot spots, of which $37 \%$ were minors [43]. It is estimated that 25,000 unaccompanied minors were kept in detention centres, often against their will and without any security guarantees, and that some detention facilities were hit by airstrikes (Protection Sector Libya 2019). The UNHCR alone has carried out 118 monitoring visits to detention facilities [44].

Our empirical research was carried intermittently between June 2013 and March 2019 in Tripoli, Tajoura, Sirte, Misrata, Benghazi, Derna and Tobruk. The interviews were conducted several times: in 2013, 2015 and 2019, in the seven centres mentioned above. The research began in 2013 at the centre in Tripoli, and then, when travel was possible, in Tajoura, Misrata, Sirte, Benghazi, Derna and finally in Tobruk, which is the closest to the Egyptian border. During fieldwork, a total of 740 minors at seven centres were interviewed: 330 in 2013, 250 in 2015 and 160 in 2019. After verification, 140 interviews were rejected on the grounds of incompleteness, unverifiable data or unreliability of field notes. As a result of tests and verifications, 600 interviews were accepted for further analysis. Of the 600 individual cases of minors that were investigated, 135 were in Tripoli (80\% boys and 20\% girls), 140 in Tajoura (74\% boys and 26\% girls), 92 in Sirte ( $85 \%$ boys, $15 \%$ girls), 40 in Misrata (60\% boys and $40 \%$ girls), 90 in Benghazi (82\% boys and 18\% girls), 63 in Derna (57\% boys and $44 \%$ girls) and 40 in Tobruk (86\% boys and $14 \%$ girls). In order to ensure diversity and empirical richness, only one child per family was admitted. With all ethical considerations in place, the children were interviewed either individually or during focus group interviews within four age categories. Minors between 10 and 14 years of age and from 14 to 18 years of age were interviewed individually. The youngest participants ( 0 to 5 years) and those between 5 and 10 years of age took part in focus groups. Focus interviews in the two youngest age groups took place in the presence of the temporary guardian, the centre's employee. It is worth mentioning that the employee turnover is so high that during subsequent visits to the sites, none of the individuals present during the initial fieldwork was still working there.

Furthermore, the physical conditions in the centres deteriorated over time as the research progressed. The best situation was in 2013, when the state was relatively stable-if we can use this phrase to describe a country that had collapsed, together with the Gaddafi regime, in 2011. In 2015, the centres were under the protection of various groups or paramilitary organisations controlling a given area. Access to the sites as well as the opportunity to talk to minors often depended on arbitrary decisions and the permission to enter. This period was the most difficult, due to the lack of stability, the incessant threat of terrorist attacks and the expansion of Daesh and organised criminal groups. 
Paradoxically, in 2019, the deteriorating humanitarian conditions and lack of water enabled full access to the centres, as they were no longer as well guarded as in previous years. There was no need to obtain a pass or even permission from the management.

In centres located in the west of the country-Tripoli, Tajoura and Sirte-an interpreter was present during the interviews because $85 \%$ of the respondents did not come from Arabic-speaking countries due to migration flows. The western Libyan trail (Tripoli, Tajoura, Syrta, Musrata) is mainly used by migrants arriving from Mauritania, Mali, Niger, Nigeria, Guinea, Ivory Coast, Burkina Faso, Senegal, Ghana, Benin and Togo, where people do not speak classic Arabic, but its regional dialects (such as hassanija, ouolof, yallof, walaf, volof and waro waro Arabic, as well as French patois and many other languages). The eastern route (Benghazi, Derna, Tobruk) is mainly used by people coming from Libya (internal migration) as well as Somalia, Chad, Sudan, Eritrea and Egypt.

Research with minors requires special methods (cf. "Interviewing Children and Young People", Esomar World Research Codes and Guidelines 2009). Nonetheless, the security situation in Libya and the constant uncertainty resulted in the inability to record and take pictures that would capture the physical environment. Even detailed notes had to be taken discreetly and usually after the interview had been concluded. Even in normal circumstances, minors are a unique and challenging research group. Additionally, most of the respondents in our study went through a traumatic journey through the desert or areas torn by conflict, lost their family, were detained or abused. All of these factors had to be taken into account on an ongoing basis, and each interview was adjusted to the individual needs and the particular situation of the respondent.

In every case, the interviewee gave explicit consent and was asked a set of standardised questions based on a semi-structured script which offered the respondents flexibility that allowed for digressions, yet kept them within the parameters of the study's interests. A qualitative methodology was adopted to enable individuals to recount experiences in their own words, highlighting what was important to them. We focused initially on descriptions provided by participants, but, as the study progressed, we took a more interpretive approach to evidence, employing the hermeneutics of trust [45] (p. 61). Such a respondent-driven approach had already been employed and proved successful in our previous research [46]. The narratives were subsequently aggregated into a "thick description" [47] and typified along the main theoretical axes that shed light on the reasons for the children's arrival in detention centres and refugee camps, the living conditions there and the potential threats to human security affecting their development, including various criminal phenomena. As the research progressed, we identified specific variables to ensure diversity in the sample. Data collection continued until the sample was diverse in terms of children's age, gender, route experiences and displacement period, and it was estimated that data saturation had been reached.

\subsection{Findings}

With respect to age breakdown, as Figure 1 shows, the respondents can be divided into the following four age groups: 

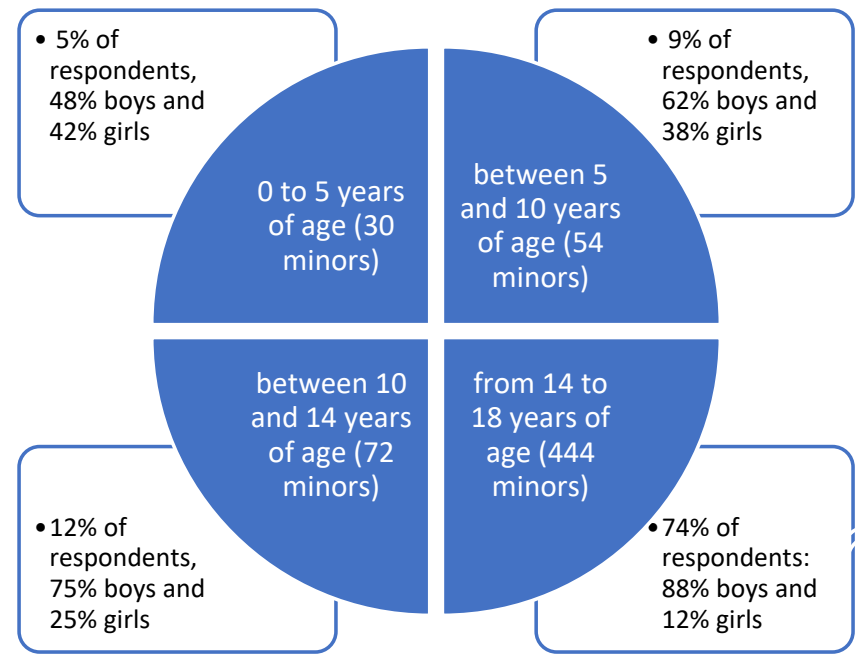

Figure 1. Age and gender breakdown of the participants.

While male adolescents constituted the majority of camp residents, most of them were also not accompanied by close family members. As shown in Table 2, most often, they migrated with distant relatives, though some were all alone.

Table 2. Family situation of interviewed minors.

\begin{tabular}{|c|c|c|c|}
\hline $\begin{array}{ll}\text { Camp } & \text { Family Situation } \\
\end{array}$ & $\begin{array}{l}\text { Migrated with } \\
\text { Close Family }\end{array}$ & $\begin{array}{c}\text { Migrated with } \\
\text { Distant Relatives }\end{array}$ & $\begin{array}{l}\text { Migrated } \\
\text { Alone }\end{array}$ \\
\hline Tripoli (135 interviewed minors) & 32 & 96 & 7 \\
\hline Tajoura (140 interviewed minors) & 30 & 85 & 24 \\
\hline Sirta (92 interviewed minors) & 8 & 46 & 38 \\
\hline Misrata (40 interviewed minors) & 6 & 11 & 23 \\
\hline Benghazi (90 interviewed minors) & 27 & 39 & 24 \\
\hline Derna (63 interviewed minors) & 45 & 15 & 3 \\
\hline Tobruk (40 interviewed minors) & 27 & 12 & 1 \\
\hline
\end{tabular}

The geographic analysis enhanced by the duration of displacement showed (Table 3), minor differences among the camps notwithstanding, a general trend of shortening of the period spent in the camp, which was particularly visible in 2019, in a stark contrast with our initial field visit, in 2013. 
Table 3. Average duration of displacement per camp per year.

\begin{tabular}{|c|c|c|c|}
\hline Camp Year & 2013 & 2015 & 2019 \\
\hline Tripoli & $\begin{array}{l}42 \text { minors interviewed, all of } \\
\text { whom had been there for a } \\
\text { minimum of } 6 \text { months: } 17 \text { from } \\
\text { 2011, } 15 \text { from } 2012 \text {, and between } \\
10 \text { and } 6 \text { months }\end{array}$ & $\begin{array}{l}57 \text { minors interviewed, of whom } 80 \% \\
\text { had been there for a minimum of } 3 \\
\text { months and } 20 \% \text { since } 2013\end{array}$ & $\begin{array}{c}36 \text { minors interviewed, } 90 \% \text { of whom } \\
\text { had been there for a minimum of } 3 \\
\text { months and } 10 \% \text { for an even } \\
\text { shorter period }\end{array}$ \\
\hline Tajoura & $\begin{array}{c}52 \text { minors interviewed, of whom } \\
70 \% \text { were displaced from } 2012, \\
21 \% \text { from } 2011 \text { and } 9 \% \text { for less } \\
\text { than a year }\end{array}$ & $\begin{array}{l}54 \text { minors, } 80 \% \text { of whom were there } \\
\text { for less than } 6 \text { months, } 15 \% \text { since } 2014 \\
\text { and } 5 \% \text { for } 3 \text { months }\end{array}$ & $\begin{array}{l}34 \text { minors, all of whom had been } \\
\text { there for } 3 \text { months }\end{array}$ \\
\hline Sirta & $\begin{array}{l}30 \text { minors interviewed, all of } \\
\text { whom had been there since } 2011\end{array}$ & $\begin{array}{l}40 \text { minors interviewed, of whom } 15 \% \\
\text { had been there for } 2 \text { months, } 23 \% \text { for } \\
3 \text { months, } 31 \% \text { for } 4 \text { months and } 69 \% \\
\text { for } 6 \text { months or longer }\end{array}$ & $\begin{array}{l}22 \text { minors interviewed, of whom } 85 \% \\
\text { had been there for } 2 \text { months and } 15 \% \\
\text { from } 6-11 \text { months }\end{array}$ \\
\hline Misrata & $\begin{array}{l}5 \text { minors interviewed, all of whom } \\
\text { had been there since } 2011\end{array}$ & $\begin{array}{l}9 \text { minors interviewed, of whom } 95 \% \\
\text { had been there for } 3 \text { months and } 5 \% \\
\text { for 5- } 6 \text { months }\end{array}$ & $\begin{array}{l}26 \text { minors interviewed, of whom } 85 \% \\
\text { had been there since } 2018 \text { and } 15 \% \\
\text { for at least } 6 \text { months }\end{array}$ \\
\hline Benghazi & $\begin{array}{l}41 \text { minors interviewed, all of } \\
\text { whom had been there since } 2011\end{array}$ & $\begin{array}{c}16 \text { minors interviewed, } 90 \% \text { of whom } \\
\text { had been there since } 2014,4 \% \text { for } 2 \\
\text { months and } 6 \% \text { for one month }\end{array}$ & $\begin{array}{l}33 \text { minors interviewed, of whom } 91 \% \\
\text { had been there for } 3 \text { months and } 9 \% \\
\text { for at least } 6 \text { months }\end{array}$ \\
\hline Derna & $\begin{array}{l}31 \text { minors interviewed, all of } \\
\text { whom had been there since } 2011\end{array}$ & $\begin{array}{l}18 \text { minors interviewed, } 89 \% \text { of whom } \\
\text { had been there since } 2013 \text { and } 11 \% \\
\text { since } 2014\end{array}$ & $\begin{array}{c}14 \text { minors interviewed, of whom } 93 \% \\
\text { had been there since } 2015 \text { and } 7 \% \\
\text { came later }\end{array}$ \\
\hline Tobruk & $\begin{array}{l}12 \text { minors, all of whom had been } \\
\text { there since } 2011\end{array}$ & $\begin{array}{l}18 \text { minors, of whom } 92 \% \text { had been } \\
\text { there since } 2011 \text { and } 8 \% \text { for one year }\end{array}$ & $\begin{array}{c}10 \text { minors were interviewed, of } \\
\text { whom } 95 \% \text { had been there since } 2015 \text {, } \\
4 \% \text { for } 2 \text { years and } 1 \% \text { for } 1 \text { year }\end{array}$ \\
\hline
\end{tabular}

Regarding the travel time to Libya and the stay in Libya as a transit country, it is worth pointing out that, on average, the children were on the road for a minimum of 5 months and stayed from 3 to 6 months, on average, in individual centres. Only five cases remained in Libya all the time, moving from camp to camp. Within the 2019 group, of the respondents from the centres in Benghazi, Derna and Tobruk, $82 \%$ had stayed in centres since 2015 , on average, and $18 \%$ since 2011 . This pattern was not present in the centres located in the west of the country. However, migration between the camps is a separate phenomenon, as we met the same people in different camps between 2015 and 2019. These places had also evolved, some having simply become neighbourhoods (in Tobruk and Derna) and others divided, such as the Benghazi camp, which by 2019 had converted into three smaller centres, each under a different organisation.

With regard to the reasons for migration or displacement, our respondents can be divided along the following axes: $40 \%$ of the respondents escaped from war and conflicts; $30 \%$ moved due to economic factors, like a loss of livelihood or expulsion; $25 \%$ were forced to migrate for personal reasons, like the need to repay debts or family vendettas. The promise of a better life (either in Europe or in Libya) was often a decisive factor in such cases. Needless to say, such promises had nothing to do with reality.

When asked about their future plans, the children offered different answers, depending mainly on the year of the study. In 2013, out of 330 minors, $70 \%$ of respondents wanted to stay in Libya with their relatives or family, although some wanted to continue to Europe as soon as possible, 30\% wanted to go to Turkey and $10 \%$ anywhere else. Naturally, the personal dreams of the children were subject to family decisions and financial possibilities. What is most important is that nobody considered returning to their place of origin. In contrast, in 2015, out of the 250 interviewed, $76 \%$ wanted to get to Europe, $10 \%$ to Egypt and $14 \%$ specifically to Turkey. Finally, in 2019, out of 160 respondents, $72 \%$ wanted to travel to Turkey or the Balkans, $14 \%$ to Europe and 14\% anywhere they could afford. In 2019, $11 \%$ of all respondents considered returning to their country of residence, provided that they received financial support and free transport. Financial considerations proved to be the critical variable. The cheapest option was both the most popular and most easily attainable: "the cheapest: it is to get to Turkey, 
then to Italy and Greece". In this respect, the change of Libya from a destination to a transit country is apparent.

As far as the mental condition of the children is concerned, it can be pointed out that $80 \%$ of them survived some trauma during migration, were often detained against their will or forced to work or break the law, most often by theft and extortion. Some children either did not want to talk about such issues or did not have such experience, although it is difficult to determine reliably. Girls were particularly vulnerable to forced marriages or sexual exploitation. The minors who travelled alone emphasised that they had to hide to avoid becoming victims of human trafficking and organised criminal groups. Those children often joined other family groups, pretending, by mutual agreement, to be a member. However, we could not verify how many respondents from the two oldest age groups told the truth when claiming they were travelling with relatives or family. Most did not have any documents and frequently were not able to accurately determine the beginning of their journey. In the two oldest age groups, illiteracy and the inability to indicate the place of origin on a map were very common. This information was deduced on the basis of language and other cultural and ethnic determinants.

The division along ethnic and national lines was an essential aspect because it was associated with the availability of medical care, food and sanitary facilities. The cultural belonging of the child determined the quality of housing, food and basic amenities, and thus had a very practical and physical dimension. The refugee children from African countries had the fewest chances and least access to these amenities; the Arab population was in a much better position, with meals, water, separate places for women and men and space for prayer. The separation into "better" and "worse" categories was palpable in each centre. Statistically, Arabs constituted $15 \%$ of the sample.

Our fieldwork shows that the worst situation was in 2015 and the best was in 2019, which is encouraging. Nevertheless, all the centres we visited were severely overpopulated and had deplorable living conditions, rife with sexual and gender-based violence and deprived of refugee and human rights standards. This makes the camps dangerous places for everyone, let alone minors, who are even more exposed to human security threats. A normal physical and mental development in such an environment is impossible, since, for these children, even everyday activities pose a danger to health and life. Furthermore, moving around the camps at night is extremely dangerous, due to harassment, rape, aggression, theft and widespread fights. In these conditions, sleeping also proves to be a challenge, and full rest is a rarity due to sharing rooms with strangers of different sexes and ages who have different intents and needs. Inadequate medical help is a separate issue, as there is one doctor or nurse, on average, per 300 people. Migrants held in the Tripoli, Tajoura, Sirte, Misrata, Benghazi, Derna and Tobruk centres are systematically subjected to starvation and severe beatings, burned with hot metal objects, electrocuted and subjected to other forms of ill-treatment to extort money from their families through a complex system of money transfers. They are frequently sold from one criminal group to another and required to pay multiple ransoms. In addition to the abuses and violence, many of them suffer from malnutrition, skin infections, acute diarrhoea, respiratory tract infections and other ailments, as well as inadequate medical treatment. Minors are held with adults in the same squalid conditions, boys and girls together, despite being from various countries of origin and different religions and cultures. All the visited centres can be classified as open, as people staying in them could move about freely and to other centres. Simultaneously, there were significant differences among centres with regard to the following criteria: control, protection and security, housing conditions, food, medical care and health requirements, access to education and level of violence.

The centre in Triq al Sika/Tripoli was under the militia protectorate and broader protection of the Libyan Task Force from the Government of National Accord. In 2015 it was closed three times, and in 2019 it could not operate according to official guidelines, which were ignored despite the ongoing fighting in the area and the frequent bombings. The number of people staying at the centre, including minors, was significantly higher than the official reports and documentation suggested. There were no safety standards in Triq al Sika. When it comes to housing conditions, children were 
assigned either to a brick building, a tent or a container, depending on their origin (Arab or African), position and financial capabilities, and had to stay where they were allocated. The accommodation was overcrowded, dirty and without access to essential utilities such as electricity, water or air conditioning. Food also depended on the place of origin and money. The oldest children indicated that they could work for access to food, thus increasing their chances of survival. Medical care in the camp was provided only in 2019 , by a doctor or a nurse who visited on a weekly basis. In previous years, contrary to official claims, it was not available. Additionally, there were several impediments to care, such as no uniform health and safety requirements and procedures. This included an insufficient number of unhygienic and poorly-ventilated toilets, as two or three toilets were shared among 400-500 migrants and, in some cases, migrants had to use a bucket. Bathrooms were located outside and guarded. People were allowed in only during fixed times, once or twice per day; access to showers was also scarce or had to be bought, a deprivation which was further exacerbated by the lack of sanitary products, including soap or menstrual hygiene products. Minors, both boys and girls, were also not subject to education and basic protection, and were exposed instead to beatings, arrests, physical punishments, harassment, rape, theft, racism and extortion of money.

The Tajoura facility, which according to UNHCR reports was closed in 2013, was under the protection of militias and non-state organisations. In 2015, the centre was managed by uniformed armed militia, some of whom swore allegiance to the so-called Islamic State (Daesh), and in 2019 the centre came under the control of grassroots organisations that were not evidenced in the Libyan legal system. Although the Tajoura centre does not officially exist, our fieldwork confirms that it still works, to the detriment of its inhabitants. There are no legal or safety regulations in place. Overcrowding, which was proven to have a negative effect on children's development [48], was just as bad at Tajoura as in the Tripoli camp, and there was no medical care or education. Living and sanitary conditions were also similar. However, because it is a relatively small centre, it was also much safer according to our respondents, many of whom came to Tajoura from Tripoli. Nonetheless, the children were exposed to racism, beatings, arrests, physical punishment, harassment, rape, theft and extortion of money, which was confirmed by 119 of 140 respondents.

The governor of the centre in Sirte changed during the study period. In 2013, it was under the control of state actors and local NGOs or militias. In 2015, together with the whole city, it was taken over by the local jihadi fighters from Ansar Al-Sharia and Daesh, while in 2019 it was already under the protectorate of the Libyan National Army (LNA), commanded by General Khalifa Haftar. In Sirte, out of 92 interviewed minors, the overwhelming majority pointed to the problems described above, but their condition was still visibly worsening by the lack of future prospects. The children talked about their desire to escape, and in many instances post-traumatic stress disorder was perceptible, although the possible causes were only alluded to in the conversations, including the experience of violence or sexual abuse by guards.

The Misrata detention centre was under the control of the Libyan Task Force from the Government of National Accord in 2013. In 2015 it was controlled by organisations affiliated with Daesh, and in 2019 operated under the control of non-governmental organisations and local militias, thanks to support from the UNHCR. Out of 40 respondents, 25 worked for food, and all pointed to problems with safety, access to water, hygiene, sanitary utilities and lack of security. The ethnic and religious divisions were also significant.

In 2013, the facility in Benghazi Ganfouda was managed by non-governmental organisations, but by 2015 , when the struggles between LNA and the Benghazi Shura Revolutionaries were beginning, the centre could be considered a no man's land, where the dominant position was held by the Islamic State of Iraq and the Levant's Libyan provinces. In 2019, the centre was under the protection of the LNA and local NGOs, including scout organisations active in the city. Housing conditions ranged from stone buildings to containers, depending on the payment made. The authorities segregated people according to their country of origin and status. For this reason, in 2019, part of the centre resembled a new district of Benghazi (which was not there in 2013). Its inhabitants (mainly of Arab origin) used 
privately purchased power generators, and some of them had access to water and even set up small workshops or services, usually hairdressers, bakeries or small shops. Simultaneously, the second part of the centre still consisted of container buildings with no access to sanitary facilities and no basic hygiene. Minors staying there were not provided with health care or education. In 2019, during our last visit, small grassroots organisations appeared, and during the Muslim festivals they provided food and organised activities for children, including both leisure and learning (elementary reading and writing).

The Derna camp was under the control of local militias and the numerous terrorist organisations already emerging in 2013. Two years later, it was managed by the Shura Council of Mujahideen in Derna, and in 2019 was under the protection of the Libyan National Army. In 2013, this facility consisted of tents and containers, which were put up by the migrants, and there was no light or water in them. In the following years, buildings appeared, and the camp melded with the city's suburbs. Nevertheless, the camp was inhabited mainly by people who came from Africa, and the interviewees repeatedly indicated that it was a dangerous a place to live in. In 2015 it was a recruitment hub, where minors were bundled by various militant organisations. Between 2013 and 2015, all the threats described above were present at the centre, including illegal arrests and kidnappings, racially aggravated assaults, harassment of a cultural and religious nature, rape of both boys and girls, and many others. In 2019, minimal services, a school for children and an informal local militia appeared in the camp.

In 2013, the site in Bab Zaytouna/Tobruk was under the control of non-state actors and local militia. In 2015 it was governed by local military factions, and in 2019 it finally fell under the protection of the Libyan National Army. Despite the lack of water, flooding and lack of hygiene, medical care and education, it was the safest of the sites we visited, especially for minors, as local militias were patrolling and guarding the residents. Furthermore, the local authorities responded to riots, fights and tensions between migrants. This centre had the lowest number of minors and the highest proportion of inhabitants of Arab origin (87\%). Many indicated that the centre was a stopgap en route to Turkey or claimed that they ended up in Tobruk after a failed attempt to cross the Mediterranean. The latter group associated migration failures with personality disorders, stress and health problems, which were further enhanced by the lack of funds for the next trip and the lack of long-term prospects for development.

The children were also very candid about the fact that there was unlimited access, in the camps, to alcohol of unknown origin and all kinds of drugs or intoxicants, while the illegal trade in absolutely everything, including humanitarian aid (blankets, bandages, medicines, etc.), was booming. Similarly, one could buy sleeping places in the camps, and access to lights, toilets and minors for sexual exploitation or for use in warfare. Even if educational programmes were theoretically offered in the camps we visited during our fieldwork, in most observed cases they were entirely fictitious, and nobody attended them in practice. Furthermore, there is an omnipresent fear and anxiety, fuelled by the quite high birth rate in the camps, often resulting from sexual abuse and lack of medical supplies. Many inhabitants of the camps attempt suicide or inflict self-harm in acts of desperation. Under such conditions, sustainable development understood as human security is not attainable for the children. In the contrary, the numerous potential threats include, among others: human trafficking; organ trade; forced prostitution; using children for smuggling; and fundamentalist radicalisation, which for many children appears to be an escape from the problems encountered in the camps and a chance for a better life, but merely leads to the military recruitment of minors, used in the ongoing fighting as cannon fodder.

These issues, undoubtedly pertinent on the individual level of analysis, are worsened by the underlying structural factors inhibiting the provision of a safe and secure environment. All the interviewed children were either directly familiar with, or had indirect knowledge of, at least one of the following problems: activities of criminal groups, militias and terrorist organisations; unstable and porous state borders (especially in the south of Libya); ubiquitous access to, and use of, weapons; 
corruption; document forgery, including passports and citizenship; the control of the Libyan ports by various armed militias and paramilitary organisations; similar control over random inland checkpoints, which are more than a hindrance for travellers, as they are often coterminous with an obligation to "pay for the journey"; contract killings; kidnappings for ransom; home robbery; rape; Islamic radicalisation; migration black markets including organ trafficking; and trafficking of women and children.

In the context of our analytical framework, it can be concluded that children are the first and most severely affected victims of the ongoing civil war, unstable political situation, local conflicts and tribal tensions. In other words, they are victims of the changes occurring in the country, and they bear the consequences of the decisions taken by their guardians. Migrant children need special protection because they are at high risk of becoming victims of violence, child trafficking or abuse or of disappearing or being separated from their families. But on the micro-level, the immediate physical environment is equally important, if not determinant in some respects. A refugee camp is a unique place, where the customary norms and elements of a normal physical environment are either not present or warped to absurdity. Furthermore, whereas the majority of scholarly research has focused on merely one aspect or impact of a given factor, it would be next to impossible to indicate one characteristic feature that affects a refugee child more than others-especially since many are inter-related. The most intimate and necessary physical element, that is, home, is often non-existent, as most of the children live in communal, dirty and overcrowded accommodation. Very often these are not even made of brick or other durable material, but are reinforced tents exposed to the elements. There is lack of both natural light and electricity and no running water or basic amenities such as toilets or showers-which are considered luxuries. These factors are coupled with a lack of even minimal privacy (or even a sleeping place), which is not only a prerequisite for mental health but often creates threats of sexual harassment for both boys and girls. The lack of basic physical safety permeates everything, and violence is everywhere. The domestic, personal and structural violence (e.g., by camp guards or vigilantes) has been rationalised or even normalised. Yet very often after traumatic experiences, children commit self-harm, mutilations or suicide attempts. These negative influences cannot be alleviated at a medical centre (defunct in most of the visited camps) or school—which, if it exists at all, is normally understaffed and lacks equipment that would allow for education (e.g., tables and chairs, but also books, notepads and writing utensils, not to mention educational materials or technical enhancements like computers or audiovisual instruments).

\section{Conclusions}

The armed conflict in Libya intensified in 2019, leaving 880,000 people in need of humanitarian assistance [43]. This was complicated, however, because political instability and violent clashes caused constant displacement and created a challenging operational environment for the UNHCR. Our case overview shows that Libya is first and foremost characterised by conflict and war. Every other factor that affects children's development is subjugated to this structural determinant. Minors in Libya, including the children of refugees and immigrants, continue to suffer due to the violence and chaos caused by the long-lasting civil war and other local conflicts. Ongoing fighting in Libya is the main reason behind the fact that $95 \%$ of minors do not attend school. Attacks on schools and the threat of violence led to the closure of many facilities and resulted in 200,000 Libyan children falling outside of the education system [37]. According to the Office for the Coordination of Humanitarian Affairs [36], 93,000 children need educational support, and 134,000 children need protection. Additionally, most of the medical infrastructure has been destroyed, water systems have been incapacitated and the waste management system has practically collapsed, which significantly increases the risk of waterborne diseases, including cholera, as well as diseases that can be prevented with vaccines, including measles [49]. Since April 2019, when fighting commenced in Tripoli and western Libya, the conditions for thousands of children and civilians have deteriorated even further. Massive attacks on populated areas have resulted in hundreds of deaths, and UNICEF has received reports of mutilation or killing of children [50]. Simultaneously, children are also recruited to fight. In this milieu, the procedures and 
policies that would guarantee and maintain the protection of children are next to non-existent. The lack of a migration framework and the relevant institutions during the Ghaddafi regime, combined with support from Europe, has led to grave human rights abuses towards migrants and refugee seekers within the country. As a consequence, Libya has witnessed the biggest exodus of migrants since World War II, and our data confirm the rising trend.

Unaccompanied and separated children (UASC) are recognised among the most vulnerable groups, especially in contexts of emergency. In December 2018, the IOM DTM estimated that $9 \%$ of the 663,000 refugees and migrants estimated to be in the country were children. Thirty-three per cent $(33 \%)$ of them, a total of 19,691 children, were unaccompanied or separated [51]. A study completed by UNICEF on the conditions of UASC in Libya in 2018, in which 288 children participated, both in Libya and Italy, found that, despite their child-specific rights, the lives of UASC in Libya were characterised by a higher level of hardship than that of adult refugees and migrants [52]. This picture emerged from the challenges reported by UASC in meeting their basic needs and accessing services, their reported working conditions and struggles with discriminatory practices to access healthcare due to being a refugee or migrant, and because of their undocumented status.

Our empirical research was carried intermittently between June 2013 and March 2019 in Tripoli, Tajoura, Sirte, Misrata, Benghazi, Derna and Tobruk. During the fieldwork, 740 minors at seven centres were interviewed and, after verification, 600 interviews were accepted for further analysis. The majority of our respondents were adolescents with 14 to 18 years of age $(74 \%)$, most of whom were male $(88 \%)$. Regarding the travel time to Libya and the stay in Libya as a transit country, our data indicate that, on average, the children were on the road for a minimum of 5 months and stayed on average from 3 to 6 months in individual centres. As for the reasons for migrating, $40 \%$ of the respondents had escaped from war and conflicts; $30 \%$ moved due to economic factors, like the loss of livelihood or expulsion; and $25 \%$ of them were forced to migrate for personal reasons, like the need to repay debts or family vendettas. The plans and dreams of the children changed during the research period: while in 2013 $70 \%$ of respondents wanted to stay in Libya with their relatives or family, two years later $76 \%$ dreamed about life somewhere in Europe. By 2019, 72\% of respondents wanted to travel specifically to Turkey or the Balkan countries. Some $80 \%$ of the interviewed children had survived trauma of one kind or another during migration, were often detained against their will and were forced to work or break the law, most often by theft and extortion. Girls were particularly vulnerable to forced marriages or sexual exploitation. These dangers prompted many unaccompanied minors to join family groups, pretending, by mutual consent, to be members.

The arrival at a centre does not mean security and safety. Migrant detention centres are in theory controlled by the Department for Combating Illegal Migration (DCIM) in the Ministry of Interior. Yet in reality, the Ministry has little authority or control over the centres. In fact, over the years, we documented how the camps were handed over like a piece of second-hand clothing from the Libyan National Army to various jihadi factions and to the Libyan Task Force of the GNA. This has crucial ramifications in terms of the daily functioning of the camps.

All the centres we visited were severely overpopulated, with deplorable living conditions, rife with sexual and gender-based violence and deprived of refugee and human rights standards. Importantly, ethnic and national divisions were associated with the provision of medical care, food and sanitary facilities. Children from sub-Saharan Africa had the least chance of access, while the Arab population was in a much better position. The conditions in the centres deteriorated over time as the research progressed; only in Benghazi and Tobruk were there some positive developments.

These places can be classified as districts of a lost future or lost generations, where crime spreads like wildfire and where sustainable development is endangered by threats stemming from the individual, community and structural levels. This should not be underestimated, because our interviews with Libyan minors show that the majority of them no longer remember stability, peace and security. These children do not know what it means to have comfortable living conditions. They have appalling definitions of health and safety. They do not have access to education or other essential 
social services. It can be said that they have lost their childhood due to a rapid and premature entry into the brutal world of adults, where they have to try to survive every day.

As the above analysis indicates, there is a robust relationship between the physical characteristics of the camps and the trauma of migration and violence, which together affect the development of minors. The most palpable ramifications are difficulties in integration (and education), due to language barriers and ignorance of culture, religion or ethnicity resulting in ambiguous mutual expectations directed both at peers and adults.

The culture shock [53] that affects nearly all refugee children also has distinct physical causes, including changed climate, light intensity, different microorganisms, food, the rhythm of life and the intensity and type of visual and sound stimuli. These are often accompanied by psychological factors for which the immediate surrounding is a catalyst: increased stress and decreased ability to cope with it; difficulties in establishing emotional connections with peers and communicating with their parents; the inadequacy of existing defence and social mechanisms caused by one's new social role and social status (including discrimination and racism); lack of a social support network; and changes in the family.

The results are both varied and grave: uncertainty, depression, anxiety, powerlessness, interpersonal conflicts, sleep disorders and health problems, including somatic and psychosomatic disorders, are rife. These children are usually profoundly traumatised by their experiences before leaving their home country (e.g., war, ethnic cleansing), as well as events occurring during migration. The physical environment of the camps, far from being a safe haven, intensifies various types of disorders in the functioning of the child, such as dissociative and adaptive disorders and acute/aggressive stress reactions anchored in a prolonged feeling of loss and regret. Many of the children experience chronic trauma caused by a long period lived in unbearable conditions. They are lost, alienated, have problems with identity and authority and often perpetuate the behaviours they have experienced and replicate the conditions they have been forced to endure.

Manuel Fontaine, the Director of the Office of Emergency Programmes at UNICEF, stated at a conference in New York, on 28 December 2017, that the scale of attacks on children is shocking [54]. UNICEF repeatedly reiterates its calls to all governments, in West and Central Africa, Europe and other parts of the world, to adopt a six-point action plan for the protection of refugee and migrant children [55]. This policy framework should protect child refugees and migrants, particularly unaccompanied children, from exploitation and violence; strive to keep families together or end the detention of migrating children seeking refugee status; provide adequate care to all refugee and migrant children; and promote measures to combat their marginalisation and abuse. Finally, the policies should also rely on international cooperation aimed at eliminating the underlying causes of large-scale movements of refugees and migrants [56]. So far, these calls have not been met with satisfactory responses, that would offer a viable policy implementation compatible with the human security paradigm. Our empirical research among the minors from the Libyan refugee camps proves these initiatives are not a political utopia or extravagant luxury, but a bare necessity.

Whereas it can be argued that the case study method has a limited potential for generalisation and limited readability due to the contextual character of the research and possible response bias, these objections are mitigated by the fact that the scale of the problem is much larger than the seven places where our empirical research was conducted. Indeed, it transcends Libyan borders. The gravity of the situation is compounded by the fact that there are as many or even more ongoing conflicts in North Africa and the Middle East. Hot spots tend to spread rather than diminish, so one should carefully anticipate an increase in the breadth and depth of the problems identified in our paper. This applies to military, economic and socio-cultural threats that strongly affect the Middle East and North Africa region, but also shape the multicultural landscape of the European Union.

Author Contributions: Conceptualization, M.E.G. and M.G.B.; Methodology, M.E.G. and M.G.B.; Analysis, M.E.G. and M.G.B.; Investigation, M.E.G.; Writing-Original Draft Preparation, M.E.G. and M.G.B.; Writing-Review \& 
Editing, M.E.G. and M.G.B.; Funding Acquisition, M.E.G. and M.G.B. All authors have read and agreed to the published version of the manuscript.

Funding: This research is financed by the Collegium Civitas statuary grant no. PB/2/2020 and the Specific University Research Grant provided by the Ministry of Education, Youth and Sports of the Czech Republic.

Conflicts of Interest: The authors declare no conflicts of interest.

\section{References}

1. Rutter, J. Refugee Children in the UK; McGraw-Hill Education: London, UK, 2006.

2. Eruyar, S.; Maltby, J.; Vostanis, P. Mental health problems of Syrian refugee children: The role of parental factors. Eur. Child Adolesc. Psychiatry 2018, 27, 401-409. [CrossRef] [PubMed]

3. Karam, E.G.; Fayyad, J.A.; Farhat, C.; Pluess, M.; Haddad, Y.C.; Tabet, C.C.; Farah, L.; Kessler, R.C. Role of childhood adversities and environmental sensitivity in the development of post-traumatic stress disorder in war-exposed Syrian refugee children and adolescents. Br. J. Psychiatry 2019, 214, 354-360. [CrossRef] [PubMed]

4. Khawaja, N.G.; Hebbani, A.; Obijiofor, L.; Gallois, C. Refugee parents' communication and relations with their children: Development and application of the refugee parent-child relational communication scale. J. Fam. Commun. 2017, 17, 372-385. [CrossRef]

5. Busch, J.; Birgit, L. Socialization and Development of Refugee Children: Chances of Childcare. In Children's Social Worlds in Cultural Context; Springer: Berlin/Heidelberg, Germany, 2019; pp. 187-200.

6. Evans, G.W. The environment of childhood poverty. Am. Psychol. 2004, 59, 77. [CrossRef] [PubMed]

7. Conteh-Morgan, E. Collective Political Violence: An. Introduction to the Theories and Cases of Violent Conflicts; Routledge: London, UK, 2004.

8. Friedman, L. Defining war. In The Oxford Handbook of War; Lindley-French, J., Yves Boyer, Eds.; Oxford University Press: Oxford, UK, 2012. [CrossRef]

9. Snow, D.M. Uncivil Wars: International Security and the New Internal Conflicts; Lynne Rienner: Boulder, CO, USA, 1996.

10. Walter, B.F. The Critical Barrier to Civil War Settlement. Int. Organ. 1997, 51, 335-364. [CrossRef]

11. Kaldor, M. New and Old Wars: Organised Violence in a Global Era; John Wiley \& Sons: London, UK, 2013.

12. Schuurman, B. Clausewitz and the "New Wars" Scholars. Parameters 2010, 40, 89-100.

13. Angstrom, J. Towards a typology of internal armed conflict: Synthesising a decade of conceptual turmoil. Civ. Wars 2001, 4, 93-116. [CrossRef]

14. Sodaro, M.J. Comparative Politics: A Global Introduction; McGraw-Hill Companies: New York, NY, USA, 2008.

15. Holsti, K.J. War, the State, and the State of War; Cambridge University Press: Cambridge, UK, 1996.

16. Hermann, C.F.; Jacobson, H.K.; Moffat, A.S. Violent Conflict in the 21st Century: Causes, Instruments \& Mitigation; American Academy of Arts and Science: Chicago, IL, USA, 1999.

17. Malešević, S. The sociology of new wars? As sessing the causes and objectives of contemporary violent conflicts. Int. Political Sociol. 2008, 2, 97-112. [CrossRef]

18. Demmers, J. Theories of Violent Conflict: An. Introduction; Routledge: London, UK, 2016.

19. Kaufmann, C.D. Interventions in Ethnic and Ideological Civil Wars: Why One Can Be Done but the Other Can't. Secur. Stud. 1996, 6, 62-103. [CrossRef]

20. Huntington, S.P. The Clash of Civilizations and the Remaking of World Order; Touchstone: London, UK, 1998.

21. International Migration Report. The United Nations. 2017. Available online: https: //www.un.org/en/development/desa/population/migration/publications/migrationreport/docs/ MigrationReport2017_Highlights.pdf (accessed on 7 January 2020).

22. Van Creveld, M. The Transformation of War; The Free Press: New York, NY, USA, 1991.

23. Cook, D.T.; John, W. (Eds.) Children and Armed Conflict: Cross-Disciplinary Investigations; Palgrave Macmillan: London, UK, 2011.

24. 2019 Concludes A 'Deadly Decade' for Children In Conflict, with More Than 170,000 Grave Violations Verified Since 2010. United Nations International Children's Emergency Fund. Available online: https://www.unicef.org/press-releases/2019-concludes-deadly-decade-children-conflictmore-170000-grave-violations-verified (accessed on 21 February 2020). 
25. More than 170,000 Children under 5 Killed by War Each Year: New Report; Save the Children. 2019. Available online: https://www.savethechildren.org.au/media/media-releases/stop-the-war-on-children (accessed on 15 February 2020).

26. United Nations Development Programme. Transforming Our World: The 2030 Agenda for Sustainable Development; Version 1; United Nations: Geneva, Switzerland, September 2015.

27. Rothschild, E. What Is Security? Dædalus 1995, 124, 58-59.

28. Buzan, B.; Hansen, L. The Evolution of International Security Studies; Cambridge University Press: Cambridge, UK, 2009.

29. Paris, R. Human security: Paradigm shift or hot air? Int. Secur. 2001, 26, 87-102. [CrossRef]

30. Huysmans, J. Defining Social Constructivism in Security Studies: The Normative Dilemma of Writing Security. Altern. Glob. Local Political 2002, 27, 41-62. [CrossRef]

31. Landman, T. Issues and Methods in Comparative Politics: An Introduction; Routledge: London, UK, 2002.

32. Peters, B.G. Comparative Politics: Theory and Methods; NYU Press: New York, NY, USA, 1998.

33. Eckstein, H. Case-study and Theory in Political Science. In Handbook of Political Science Vol. 7: Strategies of Inquiry; Fred, G., Nelson, P., Eds.; Addison-Wesley: Reading, MA, USA, 1975; pp. 79-137.

34. El Ghamari, M. Migration Crisis and the Libyan Gate to Africa. Securitologia 2016, 2, 6-12.

35. Bartoszewicz, M.G. Festung Europa; Ośrodek Mysli Politycznej: Kraków, Poland, 2018.

36. United Nations High Commissioner Refugees. Mixed Migration Trends in Libya: Changing Dynamics and Protection Challenges. 2017. Available online: https://www.unhcr.org/595a02b44.pdf\#zoom=95 (accessed on 7 January 2020).

37. International Migration Report. The United Nations. 2019. Available online: https://reliefweb.int/sites/ reliefweb.int/files/resources/DTMLibya_R26_IDPReport.pdf (accessed on 19 January 2020).

38. Working Group on Protection of Humanitarian Action. Toolkit: Responding to Violence against Humanitarian Action on the Policy Level. 2018. Available online: https:/www.actionagainsthunger.org/sites/default/ files/publications/Toolkit_-_Responding_to_Violence_Against_Humanitarian_Action.pdf (accessed on 10 February 2020).

39. International Organization for Migration. Displacement Tracking Matrix. 2019. Available online: https: //dtm.iom.int/ (accessed on 20 February 2020).

40. Amnesty International. Libya's Relentless Militia War: Civilians Harmed in the Battle for Tripoli, April-August 2019 (Index: MDE 19/1201/2019). Available online: https://www.amnesty.org/en/documents/ mde19/1201/2019/en/ (accessed on 15 January 2020).

41. International Organisation for Migration; IOM Libya. Migration Crisis Operational Framework 2017-2019. 2019. Available online: https://www.iom.int/sites/default/files/our_work/DOE/MCOF/MCOF-Libya-20172019.pdf (accessed on 20 February 2020).

42. United Nations High Commissioner Refugees. Mixed Migration Dynamics in Libya: The Impact of EU Migration Measures on Mixed Migration in Libya. 2018. Available online: https://reliefweb.int/sites/ reliefweb.int/files/resources/reach_lyb_so_mixed_migration_routes_and_dynamics_in_libya.pdf (accessed on 7 January 2020).

43. Office for the Coordination of Humanitarian Affairs, Libya: Humanitarian Response Plan. 2019. Available online: https://reliefweb.int/sites/reliefweb.int/files/resources/libya_hno_2020-fullen_final.pdf (accessed on 15 February 2020).

44. United Nations High Commissioner for Refugees. Monitoring Immigration Detention. 2019. Available online: https://www.refworld.org/pdfid/53706e354.pdf (accessed on 7 January 2020).

45. Hopf, T. The Limits of Interpreting Evidence. In Theory and Evidence in Comparative Politics and International Relations; Palgrave Macmillan: New York, NY, USA, 2007; pp. 55-84.

46. Bartoszewicz, M.G. Controversies of conversions: The potential terrorist threat of European converts to Islam. Perspect. Terror. 2013, 7, 17-29.

47. Geertz, C. Thick description: Toward an interpretive theory of culture. In The Cultural Geography Reader; Routledge: London, UK, 2008; pp. 41-51.

48. Maxwell, L.E. Multiple effects of home and day care crowding. Environ. Behav. 1996, 28, 494-511. [CrossRef] 
49. Protection Sector Libya. Update on the Protection of Civilian Situation in Libya. 2019. Available online: https://reliefweb.int/sites/reliefweb.int/files/resources/Libya\%20Protection\%20Sector\%20Update\%20on\% 20the\%20Protection\%20of\%20Civilian\%20Situation\%20in\%20Libya\%2C\%2024\%20August\%202019.pdf (accessed on 10 March 2020).

50. United Nations International Children's Emergency Fund. The Convention on the Rights of the Child at a Crossroads. 2019. Available online: https://www.unicef.org/media/62371/file/Convention-rights-child-atcrossroads-2019.pdf (accessed on 5 January 2020).

51. MHUB. Detained Youth, The Fate of Young Migrants, As ylum—Seekers and Refugees in Libya Today. 2015. Available online: http://www.mixedmigrationhub.org/wp-content/uploads/2015/07/MHUB_2015_DetainedYouth.pdf (accessed on 20 February 2020).

52. United Nations International Children's Emergency Fund. Solitary Journeys of Unaccompanied and Separated Children in Libya, Forthcoming. 2019. Available online: https://reliefweb.int/sites/reliefweb. int/files/resources/UNICEF\%20Libya\%20Humanitarian\%20Situation\%20Report\%20-\%20January-June\% 202019.pdf (accessed on 7 January 2020).

53. Ward, C.A.; Stephen, B.; Adrian, F. The Psychology of Culture Shock; Routledge: London, UK, 2001.

54. European Commission. Realizacja Europejskiego Programu w Zakresie Migracji: Postępy w Działaniach Priorytetowych. 2016. Available online: https:/ec.europa.eu/commission/presscorner/api/files/document/ print/pl/ip_16_271/IP_16_271_PL.pdf (accessed on 5 January 2020).

55. United Nations High Commissioner for Refugees. Global Report. 2018. Available online: https://www.unhcr. org/5d0a1ce47.pdf (accessed on 7 January 2020).

56. United Nations International Children's Emergency Fund. The State of the World's Children. 2019. Available online: https://www.unicef.org/media/63016/file/SOWC-2019.pdf (accessed on 6 March 2020).

(C) 2020 by the authors. Licensee MDPI, Basel, Switzerland. This article is an open access article distributed under the terms and conditions of the Creative Commons Attribution (CC BY) license (http://creativecommons.org/licenses/by/4.0/). 